\title{
Upaya Peningkatan Aktivitas Belajar Siswa Melalui Model Pembelajaran Talking Stick dengan Pendekatan Saintifik
}

\author{
Vanityas Yunita Hastuti ${ }^{*}$, Theresia Sri Rahayu², Wasitohadi $^{3}$ \\ 1,2,3 Universitas Kristen Satya Wacana, Salatiga, Indonesia
}

A R T I C L E I N F O

Article history:

Received 20 February

2019

Received in revised form

10 March 2019

Accepted 10 April 2019

Available online 20 May

2019

Kata Kunci:

Talking Stick, Saintifik, Aktivitas Belajar, Hasil Belajar

Keywords:

Talking Stick, Scientific,

Learning Activity, Learning Outcomes

\begin{abstract}
A B S T R A K
Penelitian ini merupakan penelitian tindakan kelas (PTK) yang bertujuan untuk meningkatkan aktifitas belajar peserta didik kelas III SD St. Theresia Marsudirini 77 Salatiga. Semester genap tahun ajaran 2018/ 2017 melalui penerapan Talking Stick pendekatan Saintifik. Subjek penelitian tindakan ini adalah siswa kelas III SD St. Theresia Marsudirini 77 Salatiga Tahun Pelajaran 2018/2019 yang berjumlah 44 orang. Desain Penelitian Tindakan Kelas (PTK) ini mengikuti model Stephen Kemmis yang dilakukan dalam dua siklus. Data penelitian ini dikumpulkan dengan lembar observasidan tes proyek. Data yang terkumpul dianalisis secara deskriptif kualitatif dan deskriptif kuantitatif. Hasil penelitian menunjukkan bahwa penerapan pembelajaran Talking Stick pendekatan Saintifik dapat meningkatkan aktifitas belajar peserta didik dalam pembelajaran tematik, hal ini dapat dilihat dari ketuntasan belajar siswa dari $41 \%$ menjadi (75\%). Setelah diberikan tindakan siklsu II, terjadi lagi peningkata menjadi (88\%). Dengan hasil ini dapat dikatakan meningkatnya hasil belajar Tematik dan Aktivitas Belajar peserta didik menggunakan pembelajaran Talking Stick dengan Pendekatan Sanitifik, berhasil dalam meningkatkan hasil belajar peserta didik dan aktivitas belajar peserta didik dalam pembelajaran Tematik pada peserta didik kelas 3 SD St. Theresia Marsudirini 77 Salatiga, Semester 2 2018/2019.
\end{abstract}

A B S T R A C T

This research is a classroom action research (CAR) which aims to improve the learning activities of third grade students of SD St. Theresia Marsudirini 77 Salatiga. Even semester 2018/2017 through the implementation of the Talking Stick Scientific approach. The subject of this action research is third grade students of SD St. Theresia Marsudirini 77 Salatiga 2018/2019 Academic Year totaling 44 people. This Classroom Action Research (CAR) design follows the Stephen Kemmis model conducted in two cycles. The research data was collected by observation sheets and project tests. The collected data were analyzed by descriptive qualitative and quantitative descriptive. The results showed that the application of Talking Stick Scientific approach can improve students 'learning activities in thematic learning, this can be seen from students' mastery learning from $41 \%$ to (75\%). After cyclic II action was given, the increase was increased to (88\%). With these results it can be said that the increase in the results of Thematic learning and Learning Activities of students using Talking Stick learning with the Sanitic Approach, succeeded in improving student learning outcomes and learning activities of students in Thematic learning on 3rd grade students of SD St. Theresia Marsudirini 77 Salatiga, Semester 2 2018/2019. 


\section{Pendahuluan}

Pendidikan merupakan suatu kebiasaan sekelompok orang yang diturunkan dari satu generasi ke generasi berikutnya melalui pengajaran, pelatihan, atau penelitian Menurut undang-undang Republik Indonesia No 20 Tahun 2003 Tentang Sistem Pendidikan Nasional, bahwa pendidikan adalah usaha sadar dan terencana untuk mewujudkan suasana belajar dan proses pembelajaran agar siswa secara aktif membangun potensi dirinya untuk memiliki kekuatan spiritual keagamaan, pengendalian diri , kepribadian, kecerdasan, ahlak mulia serta keterampilan yang diperlukan dirinya, masyarakat, bangsa dan negara.

Sementara itu undang-undang Sistem Pendidikan Nasional No. 20 tahun 2003 menyatakan bahwa kurikulum merupakan sebuah seperangkat rencana dan peraturan mengenai tujuan, isi, dan bahan pelajaran serta cara yang digunakan sebagai pedoman penyelenggaraan pembelajaran untuk mencapai tujuan pendidikan tertentu. Kurikulum yang digunakan di Indonesia sendiri saat ini adalah kurikulum 2013 revisi 2016. Kurikulum 2013 dikembangkan atas dasar teori pendidikan berdasarkan standar (standard-based education), dan teori kurikulum berbasis komptensi (Majid Abdul, 2014:33). Pada kurikulum 2013 pula terdapat berbagai macam revisi dan revisi terbaru dilakukan pada tahun 2016 dan di dalam kurikulum 2013 pembelajrannya berdasarkan tema. Pelaksanaan pembelajaran Kurikulum 2013 mengamanatkan penggunaan pendekatan ilmiah. Pendekatan ilmiah (scientific approach) adalah pendekatan yang menonjolkan dimensi pengamatan, penalaran, penemuan, pengabsahan, dan penjelasan mengenai suatu kebenaran. Pendekatan ini memberi kesempatan untuk meningkatkan kemampuan peserta didik dalam melakukan observasi, bertanya, menalar, dan mengomunikasikan pengetahuan yang diperoleh dari proses pembelajaran. Melalui tahapan-tahapan dalam pembelajaran yang berpendekatan ilmiah (scientific approach), peserta didik dibimbing secara bertahap untuk mengorganisasikan dan melakukan penelitian. Proses pembelajaran dengan scientific approach meliputi ranah kognitif, psikomotorik, dan afektif sehingga membentuk peserta didik yang kreatif, produktif, dan inovatif melalui penguatan yang terintegrasi antara pengetahuan, keterampilan, dan sikap.

Sejalan dengan pendekatan tersebut, model pembelajaran dalam kurikulum 2013 juga disarankan salah satunya model pembelajaran Talking Stick. Model pembelajaran kooperatif talking stick meminimalkan terjadinya monopoli kelas oleh siswa-siswa yang pintar, sehingga siswa-siswa yang kurang pintar juga dapat untuk mengemukakan pendapatnya (Puspitawangi, 2016). Sintak dari model pembelajaran talking stick adalah guru menyiapkan tongkat, sajian materi pokok, siswa membaca materi, guru mengambil tongkat dan memberikan tongkat kepada siswa dan siswa yang kebagian tongkat menjawab pertanyaan dari guru, tongkat diberikan kepada siswa lain dan guru memberi pertanyaan lagi dan seterusnya (Megawati, 2013).

Pada pembelajaran Tematik agar peserta didik mampu memahami persoalan mengidnetifikasi sebuat pokok bahasan pengetahuan dan menggali pengetahuan peserta didik mengenai hak dan kewajiban disekolah, dirumah dan dimasyarakat, berdasarkan rasa ingin tahu oleh peserta didik terkait fenomena atau kejadian yanga ada di lingkungan peserta didik. Untuk kompetensi inti atau keterampilan peserta didik diharapaka mampu mencoba, mengolah dan menyajikan dalam ranah konkret atau menggunakan dan lebih baik membuatnya dengan bahasa lisan menurut pemahaman dan bahasa peserta didik sesuai yang pembelajaran yang dipelajari ataupun dari sumber pembelajaran yang lain. Sehingga pemilihan model pembelajaran Talking Stick sangat cocok diterapkan. Materi ini juga menuntut kesiapan bahan pembelajaran dan alat yang dipakai saat kegiatan pembelajaran berlangsung secara pribadi ataupun berkelompok. Dari sinilah muncul permasalahan dalam pembalajaran bahwa aktivitas belajar peserta didik kelas III SD St. Theresia Marsudirni 77 Salatiga disemester genap 2018/2019 terindikasi kepada peserta didik yang kurang fokus dalam aktivitas belajar atau lebih melakukan kegaiatan yang tidak dalam konteks aktivitas belajar di dalam kelas. Terjadinya hal tersebut memungkinkan peserta didik: malas untuk mengikuti pembelajaran, pembelajaran yang kurang memikat hati peseta didik, dan konsentarasi peserta didik dalam pembelajaran kurang. Akibatnya dengan aktivitas belajar peserta didik kurang kondusif, kurang terfokus, dan peserta didik tidak menghayati pembelajaran di kelas. Sehingga penyelesaian tugas peserta didik kurang makmimal dan kurang sesuai dengan harapan yang sesuia dengan pendidikan bermakna sebagai sistem pendidikan memiliki tiga ciri, yaitu mensejahterakan, menghargai martabat manusia, dan berkeadilan.Implikasinya bagi pendidikan, bahwa (a) pendidikan harusberorientasi pada subyek didik, artinya anak didik diperlakukan sebagai subyek, pendidikan diselenggarakan sesuai dengan perkembangan dan kemampuan anak, dan pendidikan itu mengembangkan anak didik secara utuh, (b) pendidikan yang dikembangkanharus humanis religius, yaitu pendidikan yang menekankan aspek kemerdekaan individu diintegrasikan dengan pendidikan religius agar dapat membangun kehidupan individu (sosial) yang memiliki kemerdekaan dan kemandirian, tetapi dengan tidak meninggalkan nilainilai keagamaan yang diikuti masyarakatnya, atau menolak nilai 
ketuhanan (ateisme), dan (c) kebijakan pendidikan yangdeliberatif,sehinggakebijakan pendidikan yang dibuat memiliki hasil optimal (Wasitohadi 2012 :85)

Berdasarkan permasalagan tersebut perlu diterapkan model pembelajaran Talking Stcik dengan pendekatan saintifik. Metode ini mengedepankan peran aktif peserta didik dalam pembelajaran, sedangkan guru sebagai fasilitator dan instruktor dalam membantu peserta didik menemukan dan mengonstruksikan pengetahuan yang dipelajarinya.

Berdasarkan penjabaran pada latar belakang tersebut maka dipandang pelu untuk melakukan penelitian yang dituangkan dalam judul :"Upaya Peningkatn Aktvitas Belajar Siswa Kelas II Semseter II Tahun Pelajaran 2018/2019 SD St. Theresia Marsudirini 77 Salatiga Melalui Model Pembelajaran Talking Stick Dengan Pendekatan Saintifik."

Sehubungan dengan latar belajar permasalahan, dapat dirumuskan permaslaahn sebagai berikut, apakah pendekatan saintifik dan model pembelajaran talking stick mampu mengupayakan peningkatan aktifitas belajar siswa kelas III SD St. Theresia Marsudirini 77 Salatiga. Dan dengan bagaimana langkahlangkah untuk mengupayakan peningkatan aktifitas belajar siswa kelas III SD St. Theresia Marsudirini 77 Salatiga melalui pendketan sainstifik dan model pembelajaran talking stick.

Tujuan yang dicapai dalam penelitian tindakan kelas ini adalah: Untuk mengetahui apakah pendekatan sanistifik dan model pembelajaran talking stick mampu menguapayakan peningkatan aktifitas belajar siswa kelas II SD St. Theresia Marsudirini 77 Salatiga. Dan dengan Untuk mengetahui bagaimana langkah-langkah untuk mengupayakan peningkatan aktifitas belajar siswa kelas III SD St. Theresia Marsudirini 77 Salatiga melalui pendektan sainstifik dan model pembelajaran talking stick.

Hasil penelitian tindakan kelas ini diharapkan memiliki manfaat secara parktis dan teoritis. Kedua manfaat dapat diuraikan beriku ini: Manfaat praktis dari penelitaian ini yaitu: Manfaat teroritis penelitian ini yaitu untuk member terori mengenai upaya peningkatan aktifitas belajar siswa kelas III SD St. Theresia Marsudirini 77 Salatiga pada semester I tahun pelajaran 2018/2019 melalui pendketaan sainstifik dan model pembelajaran talking stick.

\section{Metode}

Setting penelitian tindakan ini dilakukan di SD St. Theresia Marsudrini 77 Salatiga. SD St. Theresia Marsudrini 77 Salatiga berlokasi di Jalan Senuri No.15, Sidorejo, Salatiga, Jawa Tengah. Penelitian ini dilaksanakan pada tanggal 31 Januari sampai 16 Februari 2019. Penelitian dilaksankan pada 2 siklus yang dimana setiap siklusnya mempunya 3 tahapan yaitu Pertemuan 1, Pertemuan 2, dan Evaluasi serta Refleksi. Guru dan staff di SD St. Theresia Marsudirini 77 Salatiga berjumlah 18 orang yang terdiri dari 1 kepala sekolah, 6 guru kelas, 1 guru mata pelajaran Bahasa Inggris, 1 guru mata pelajaran PJOK, 1 Pengurus perustakaan, 1 guru Lab Bahasa Indonesia , 1 guru Lab komputer, 1 staf TU sekolah, serta 3 penjaga sekolah.

Peneliti terlebih dahulu melakukan observasi untuk mengetahui kondisi awal sebelum dilakukan pelaksanaan tindakan. Berdasarkan observasi yang dilakukan ada pembelajaran Tematik dan berdiskusi dengan guru kelas ditemukan beberapa permasalahan diantaranya peserta didik sering sibuk bermain atau melakukan aktivitas yang kurang terfokus dalam memperhatikan guru dalam pembelajaran, peserta didik kurang bertanggung jawab dalam melakukan kegiatan mengerjakan tugas dan kurangnya berkerjasama dengan teman lain. Sehingga aktivitas belajar peserta didik kurang terfokus dalam pembelajaran tematik.

PTK bertujuan untuk memperbaiki berbagai persoalan nyata guru dalam pengembangan profesionalnya. Prosedur penelitian meliputi refleksi awal, rencana tindakan, pelaksanaan tindakan, observasi atau evaluasi, refleksi. Refleksi merupakan kegiatan mengkaji, menganalisis, observasi dan evaluasi untuk melakukan revisi. Hasilnya digunakan untuk menyusun rencana tindakan untuk melakukan tindakan yang baru pada siklus I. Hal serupa dilakukan juga pada akhir siklus II. Kegiatan itu berhenti setelah diproleh keputusan atau penentuan hasil tindakan terbaik. Rancangan dalam penelitian ini menggunakan siklus dengan model penelitian tindakan kelas Stephen Kemmis yang direncanakan sebanyak 2 ( dua ) kali siklus dengan masing-masing siklus terdiri dari empat tahapan yaitu: 1) perencanaan (planning), b) tindakan pelaksanaan (action), c) observasi dan evaluasi (observation and evaluation), dan d) refleksi (reflection) (Santyasa, 2006: 10). Setiap selesai satu siklus selalu dilakukan refleksi terhadap proses pembelajaran yang telah dilaksanakan. Refleksi ini dilakukan berdasarkan hasil observasi dan hasil evaluasi. Jika hasil observasi dan hasil evaluasi belum sesuai dengan harapan, maka dilanjutkan tindakan pembelajaran pada siklus berikutnya. Jika ternyata belum ada peningkatan aktivitas yang memadai seperti yang diharapkan, tindakan-tindakan proses pembelajaran itu didaur ulang pada siklus berikutnya dengan diadakan perbaikan (modifikasi), namun yang dipandang sudah baik tetap dipertahankan. Jenis data dalam PTK ini berupa data kualitatif dan kuantitatif. Jenis data kualitatif 
penelitian ini berupa aktifitas belajar peserta didik dan respon peserta didik terhadap pembelajaran yang telah diikuti. Jenis data kuantitatif penelitian ini berupa hasil keaktifan dan hasil belajar individual. Kedua jenis data tersebut bersumber dari kegiatan pembelajaran yang dilakukan selama dua siklus dengan tiap siklus satu kali pertemuan.

\section{Hasil dan Pembahasan}

Berdasarkan hasil observasi awal yang dilakukan ada pembelajaran Tematik dan berdiskusi dengan guru kelas ditemukan beberapa permasalahan diantaranya peserta didik sering sibuk bermain atau melakukan aktivitas yang kurang terfokus dalam memperhatikan guru dalam pembelajaran, peserta didik kurang bertanggung jawab dalam melakukan kegiatan mengerjakan tugas dan kurangnya berkerjasama dengan teman lain. Sehingga aktivitas belajar peserta didik kurang terfokus dalam pembelajaran tematik. Hal ini dapat dilihat pada hasil aktivitas belajar Tematik Tema 5, Subtema 1, Pembelajaran 3 peserta didik kelas 3 SD St. Theresia Marsudirni 77 Salatiga pada pra siklus jumlah siswa pada kriteria kurang jumlahnya 16 peserta didik atau 36\% peserta didik. Sedangkan jumlah peserta didik yang berada di kriteria cukup berjumlah 14 peserta didik atau 32\% peserta didik. Juga terdapat jumlah peserta didik pada kriteria baik berjumlah 8 atau $18 \%$ peserta didik dan pada kriteria baik sekali berjumlah 6 atau 14 $\%$ peserta didik. Rata-rata yang diperolah pada pra siklus 55 dimana masih berada pada kriteria kurang perlu ditingkatkan lagi.

Hal yang sama juga terjadi pada hasil Belajar siswa. Diketahui bahwa hasil belajar Tematik peserta didik kelas 3 SD St. Theresia Marsudirni 77 Salatiga masih cukup rendah, hal ini dapat dilihat dari banykanya siswa yang belum menuntaskan nilai sesuai dengan KKM yang telah ditentukan yaitu kurang lebih 75. Hal ini dapatdilihat pada Tabel 1 dan diagram dibawah ini.

Tabel 1. Hasil Belajar Tematik peserta didik kelas 3 SD St. Theresia Marsudirni 77 Salatiga

\begin{tabular}{llllll}
\hline $\mathrm{N}$ & NILAI & FREKUENSI & PRESENTASE (\%) & AKTIVITAS BELAJAR & FREKUENSI \\
0 & & & & & \\
\hline 1 & $45-58$ & 8 & 18 & $0-20 \%$ & 2 \\
2 & $59-74$ & 18 & 42 & $20 \%-40 \%$ & 8 \\
3 & $75-86$ & 13 & 29 & $40 \%-60 \%$ & 21 \\
4 & $87-100$ & 5 & 11 & $60 \%-80 \%$ & 7 \\
5 & & & $80 \%-100 \%$ & 44 \\
Jumlah & 44 & & Jumlah Peserta didik & $60 \%$ \\
Rata-rata & 73 & & Rata-Rata Aktivitas & $100 \%$ \\
Nilai Tertinggi & 100 & & Aktivitas Tertinggi & $15 \%$ \\
Nilai Terendah & 45 & & Aktivitas Terendah & \\
\hline
\end{tabular}

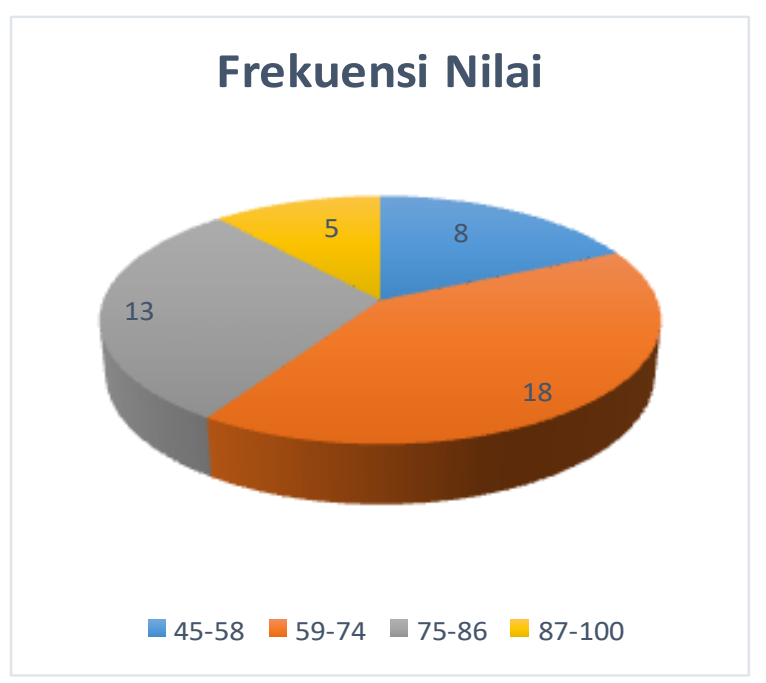

Gambar 1. Diagram Hasil Belajar Tematik peserta didik kelas 3 SD St. Theresia Marsudirni 77 Salatiga 
Berdasarkan Tabel 1 dan gambar 1 diatas diketahu bahwa peserta didik yang mendapat rentang nilai 45-58 dengan kategori belum mencapai KKM sebanyak 8 peserta didik atau 18\% dari keseluruhan peserta didik, peserta didik yang mendapatkan nilai 59-74 dengan kategori belum mencapai KKM sebanyak 18 peserta didik atau 42\% dari keseluruhan peserta didik, peserta didik yang mendapat rentang nilai 75-86 dengan kategori tuntas ada 13 peserta didik atau 29\% peserta didik dari keseluruhan peserta didik, dan peserta didik yang mendapatkan nilai 87-100 ada 5 peserta didik atau 11\% dari keseluruhan peserta didik. Nilai rata-rata adalah 73 dengan nilai tertinggi adalah 100 sedangkan nilai terendah adalah 45.

Hasil observasi selanjutnya yaitu observasi terhadap aktivitas belajar peserta didik pada pembelajaran tematik kelas 3 SD St. Theresia Marsudirini 77 secara keseluruhan memperoleh hasil aktivitas belajar masih cukup rendah, hal ini dapat dilihat dari banyaknya peserta didik yang belum menunjukan 100\% Aktivitas Belajarnya di pembelajaran Tematik dalam kelas.Hal ini dapat dilihat pada Tabel 2 dan gambar 2 di bawah ini.

Tabel 2. Hasil aktivitas belajar peserta pada pembelajaran tematik kelas 3 SD St. Theresia Marsudirini 77

\begin{tabular}{lllll}
\hline No & Nilai Aktivitas Belajar & Kriteria & Jumlah Siswa & Presentase (\%) \\
\hline 1 & $0>20 \%$ & Sangat Kurang & - & - \\
& & & & \\
2 & $20 \%>40 \%$ & Kurang & 16 & 36 \\
3 & $40 \%>60 \%$ & Cukup & 14 & 32 \\
4 & $60 \%>80 \%$ & Baik & 8 & 18 \\
5 & $80 \%>100 \%$ & Baik Sekali & 6 & 14 \\
& Jumlah & & 44 & 100 \\
& Rata-rata & & 55 \\
& Tertinggi & & 92 \\
& Terendah & & 38 \\
\hline
\end{tabular}

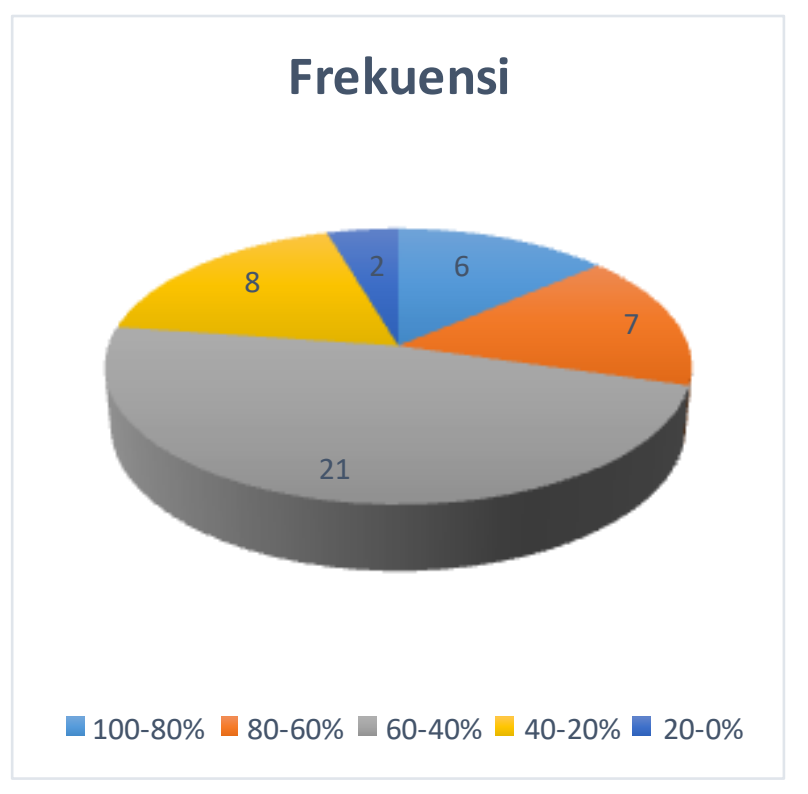

Gambar 2. Diagram Hasil aktivitas belajar peserta pada pembelajaran tematik kelas 3 SD St. Theresia Marsudirini 77

Berdasarkan Tabel 2 dan gambar di atas dapat dideskripsikan bahwa peserta didik yang mendapat rentang 0-20\% sebanyak 2 peserta didik, pada kategori 20\%-40\% terdapat 8 peserta didik, peserta didik dalam rentang nilai 40\%-60\% terdapat 21 peserta didik, juga pada kategori $60 \%-80 \%$ hanya 7 peserta didik dan yang mendapat rentang aktivitas belajar 80\%-100\% hanya ada 6 peserta didik dari keseluruhan peserta didik. 
Sebelum dilakukan tindakan, peserta didik yang tuntas belajar adalah 18 peserta didik atau 41\% dari 44 peserta didik. Setelah diberikan tindakan pada siklus I, terjadi pertambahan peserta didik yang tuntas menjadi 33 peserta didik (75\%). Setelah diberikan tindakan siklsu II, terjadi lagi peningkatan menjadi 39 peserta didi (88\%).

Peserta didik yang sebelum tuntas sebelum diberikan tindakan adalah 26 atau 59\% dari keseluruhan peserta didik. Setelah diberikan tindakan pada siklus I, terjadi penurunan menjadi 11 peserta didik (25\%) yang belum tuntas. Dengan hal ini di berikan lagi tindakan pada siklus II terjadi penurunan peserta didik menjadi 5 peserta didik atau 11\% dari jumlah keseluruhan peserta didik. Dengan hasil ini dapat dikatakan meningkatnya hasil belajar Tematik dan Aktivitas Belajar peserta didik menggunakan pembelajaran Talking Stick dengan Pendekatan Sanitifik, berhasil dalam meningkatkan hasil belajar peserta didik dan aktivitas belajar peserta didik dalam pembelajaran Tematik pada peserta didik kelas 3 SD St. Theresia Marsudirini 77 Salatiga, Semester 2 2018/2019.

Selain meningkatkan hasil belajar Tematik, hasil penelitian juga membuktikan bahwa menggunkan pembelajaran Talking Stick dengan pendekatan Sanitifik membuktikan bahwa mampu meningkatkan aktivitas belajar peserta didik. Hal ini dibuktikan dengan, pada siklus I aktivitas belajar peserta didik dalam mengikut proses pembelajaran dengan Talking Stick dan pendekatan Sanitifik berada pada kategori baik dengan nilai 75. Setelah dilakukan perbaikan-perbaikan kinerja pada siklus II, terjadi peningktan aktivitas belajar dalam mengikuti kegiatan pembelajaran Talking Stick dengan pendekatan Saintifik berada pada kategori baik sekali dengan nilai 84 .

Penerapan model Talking Stick membuat pembelajaran lebih menyenagkan dan edukatif, secara metal peserta didik mendorong semangat dalam berkelompok peserta didik menjawab setiap pertanyaan yang diajukan oleh guru dengan rasa percaya diri. Juga dalam berkelompok menjadikan peserta didik paham bagaimana caranya memberi saran atau medengarkan pendapat dari peserta didik yang lain. Hal ini sesuai dengan model pembelajaran Talking Stick mengembangkan sikap saling menghargai pendapat dan memberikan kesempatan pada orang lain untuk mengemukakan gagasannya denan menyampaikan pendapat mereka secara berkempok. Langkah-laangkah penerapan Model Pembelajaran Talking Stick diawali dengan penjelasan guru mengenal materi pokok yang akan dipelajari. Kemudian dengan bantuan Stick (tongkat) yang bergulir di setiap kelompok peserta didik dituntun untuk merefleksikan atau mengulang kembali materi yang sudah dipelajari dengan menjawab pertanyaan dari guru. Siapa yang memegang tongkat yang wajib menjawab pertanyaan (talking). Menerapkan model pembelajaran Talking Stick dengan pendekatan Sanitifik memungkinkan peserta didik untuk terlebat lebih aktif, peserta didik mengali pengetahuan dari rekan sekitarnya, peserta didik berperan lebih dalam pembelajaran, sehingga memungkinkan peserta didik untuk meningkatkan aktifitas belajar peserta didik dan hasil belajar peserta didik.

Teori menyebutkan bahwa aktivitas siswa merupakan prinsip atau asas yang sangat penting dalam interaksi belajar mengajar (Sardiman, 2006: 96). Saat pembelajaran berlangsung siswa mampu memberikan umpan balik terhadap guru. Sardiman (2006: 100) menyatakan bahwa aktivitas belajar merupakan aktivitas yang bersifat fisik maupun mental. Dalam kegiatan belajar keduanya saling berkaitan. Terdapat sembilan aspek untuk menumbuhkan aktivitas siswa dalam kegiatan pembelajaran, salah satunya yaitu memberikan motivasi pada siswa untuk aktif dalam kegiatan pembelajaran dengan memberikan reward (Martinis Yamin, 2007: 84). Arikunto Suharsimi menyebutkan bahwa reward merupakan dua bentuk metode untuk memotivasi seseorang untuk melakukan kebaikan dan meningkatkan prestasinya. Terdapat kaitan dengan pengertian prestasi belajar dengan menyatakan bahwa: prestasi adalah penilaian pendidikan tentang perkembangan dan kemajuan murid yang berkenaan dengan penguasaan bahan pelajaran yang disajikan kepada mereka dan nilai-nilai yang terdapat di dalam kurikulum. Hasil produk peserta didik, jika dibandingkan dari sebelum diadakan tindakan ke tindakan siklus pertama dan kedua mengalami peningkatan dan tercapainya indikator atau kriteria keberhasilan yang ditetapkan. Hal ini disebabkan karena dengan diberikannya reward berupa angka (nilai bonus) sehingga memotivasi peserta didik. Temuan ini sejalan dengan pernyataan Woodruff. Menurut Woodruff yang dikutip oleh Callahan (dalam http://wijayalabs.wordpress.com) dikatakan bahwa sesungguhnya proses belajar tidak terjadi tanpa adanya minat atau perhatian dari yang belajar. Bahkan, Keller yang dikutip Reigeluth (1987:383, dalam http://wijayalabs.wordpress.com) mengemukakan bahwa dalam kegiatan pembelajaran, minat atau perhatian tidak hanya dibangkitkan, melainkan juga harus dipelihara selama proses pembelajaran berlangsung. Dengan tumbuhnya minat ini peserta didik akan selalu dan terus untuk belajar. 


\section{Simpulan Dan Saran}

Berdasarkan hasil analisis data maka dengan demikian dapat disimpulkan bahwa pembelajaran Think Pair Share dapat meningkatkan motivasi belajar yang ditandai pula dengan meningkatkatnya hasil belajar Tematik pada peserta didik kelas III SD St. Thersia Marsudrini 77 Salatiga Semester 2 Tahun 2018/2019. Hal ini dibuktikan dengan hasil penelitian sebagai berikut: Peningkatan aktivitas belajar peserta didik. Pada siklus I aktifitas belajar peserta didik dalam mengikuti pembelajaran dengan pembelajaran Talking Stick berada pada kategori baik dengan nilai 75. Setelah dilakukan perbaikanperbaikan dengan memberikan peran yang berbeda-beda dalam kelompok, pada siklus II, terjadi peningkatan aktivitas belajar peserta didik dalam mengikuti pembelajaran dengan menggunakan model pembelajaran Talking Stick berada pada kategori baik sekali dengan nilai 84. Peningkatan aktivitas belajar peserta didik juga ditandai dengan meningkatnya hasil belajar peserta didik. Sebelum tindakan, peserta didik yang tuntas belajar adalah $18(41 \%)$ dari 44 peserta didik. Setelah diberikan tindakan pada siklus I, terjadi pertambahan peserta didik yang tuntas menjadi 33 peserta didik (75\%). Setelah diberikan tindakan pada siklus II, terjadi lagi peningkatan ketuntasan belajar peserta didik menjadi 39 peserta didik $(88 \%)$.

Berdasarkan simpulan di atas, penulis mengajukan beberapa saran berikut: 1) Guru-guru pengampu mata pelajaran Seni Budaya disarankan untuk menerapkan model pembelajaran Talking Stick berbantuan pendekatan Saintifik untuk meningkatkan aktivitas dan prestasi belajar peserta didik dengan tetap memperhatikan karakteristik peserta didik yang dihadapi, 2) Dalam penelitian ini, pemberian pertanyaan yang digunakan sebagai pemicu semangat siswa dalam proses pelaksanaan pembelajaran dalam tiap siklus berupa nilai bonus atau tambahan, karena itu agar diperoleh hasil yang lebih valid perlu dilakukan penelitian lanjutan dengan pertanyaan jenis lain sehingga banyak peluang bagi peserta didik sebagai penyemangat belajar.

\section{Daftar Rujukan}

A.M, Sardiman. 2006. Interaksi dan Motivasi Belajar- mengajar. Jakarta: PT Raja Grafindo Persada

Fajri, N., Yoesoef, A. and Nur, M., 2017. Pengaruh Model Pembelajaran Kooperatif Tipe Talking Stick Dengan Strategi Joyful Learning Terhadap Prestasi Belajar Siswa Pada Mata Pelajaran IPS Kelas VII MTsN Meuraxa Banda Aceh. Jurnal Ilmiah Mahasiswa Jurusan Pendidikan Sejarah, 1(1).

Isjoni. 2009. Pembelajaran Kooperatif. Yogyakarta: Pustaka Pelajar

Lisdayanti, N.P., Ardana, I.K. and Abadi, I.B.G.S., 2014. Pengaruh Model Pembelajaran Kooperatif Talking Stick Berbantuan Media Gambar Terhadap Hasil Belajar IPA Siswa Kelas V SD Gugus 4 Baturiti Di Kabupaten Tabanan. Mimbar PGSD Undiksha, 2(1).

Megawati, N.M.P., Suarni, N.K. and Sulastri, M., 2013. Penerapan model pembelajaran talking stick berbantuan media gambar berseri untuk meningkatkan kemampuan berbahasa lisan. Jurnal Pendidikan Anak Usia Dini Undiksha, 1(1).

Puspitawangi, K.R., Wibawa, I.M.C. and Pudjawan, K., 2016. Pengaruh Model Pembelajaran Kooperatif Tipe Talking Stick Berbantuan Media Audio Terhadap Hasil Belajar IPS Siswa. MIMBAR PGSD Undiksha, 4(1).

Pranyandari, N.M., Negara, I.G.A.O., Ke, S.P.M., Suardika, I.W.R. and Si, M., 2014. Pengaruh Model Pembelajaran Talking Stick Berbasis Concept Mapping terhadap Hasil Belajar IPA Siswa Kelas V Sekolah Dasar Gugus IV Kuta Utara Tahun Ajaran 2013/2014. MIMBAR PGSD Undiksha, 2(1).

Ridwan Abdullah Sani, 2014Pembelajaran Saintifik Kurikulum 2013, Jakarta, PT. Bumi Aksara,), h. 178179

Santyasa. 2006. Penelitian Tindakan Kelas: Konsep dasar, Teknik Penyusunan Proposal, dan Sistematika Laporan Penelitian (makalah). Singaraja: Universitas Pendidikan Ganesha 
Sharon E. Smaldino, Deboran L Lowther, James D, Russel, 2011, Intrucsional Technilogy \& Media For Learning Teknologi Pembelajaran dan Media untuk Belajar, Kencana , Jakarta.

Siregar, S., 2017. Pengaruh Model Pembelajaran Talking Stick Terhadap Hasil Belajar dan Aktivitas Visual Siswa pada Konsep Sistem Indra. BIOTIK: Jurnal Ilmiah Biologi Teknologi dan Kependidikan, 3(2), pp.100-106.

Suherman, M. 2008. Model Belajar dan Pembelajaran Berorientasi Kompetensi Siswa.

Wasitohadi. 2012 Mengembangkan Pendidikan Bermakna Di Indonesia dan Implikasi-Implikasinya.

Zainal Aqib, 2013, Model-Model, Media dan Strategi Pembelajaran Kontekstual (inovatif), Bandung, CV Yrama Widya, h. 66. 